\section{ECRG4 expression in normal rat tissues: expression study and literature review}

\author{
A. Porzionato, ${ }^{1}$ M. Rucinski, ${ }^{2}$ \\ V. Macchi, ${ }^{1}$ G. Sarasin, ${ }^{1}$ \\ L.K. Malendowicz, ${ }^{2}$ R. De Caro' \\ 'Section of Human Anatomy, Department \\ of Molecular Medicine, University \\ of Padua, Italy \\ 2Department of Histology and \\ Embryology, Poznan University \\ of Medical Sciences, Poland
}

\section{Abstract}

The Esophageal Cancer Related Gene 4 (ECRG4) is a highly conserved tumour suppressor gene encoding various peptides (augurin, $\mathrm{C} \Delta 16$ augurin, ecilin, argilin, $\mathrm{C} \Delta 16$ argilin) which can be processed and secreted. In the present work, we examined ECRG4 expression and location in a wide range of rat organs and reviewed the available literature. ECRG4 mRNA was identified in all examined tissues by quantitative PCR (qPCR). ECRG4 immunoreaction was mainly cytoplasmic, and was detected in heart and skeletal muscles, smooth muscle cells showing only weak reactions. In the digestive system, ECRG4 immunostaining was stronger in the esophageal epithelium, bases of gastric glands, hepatocytes and pancreatic acinar epithelium. In the lymphatic system, immunoreactive cells were detectable in the thymus cortex, lymph node medulla and splenic red pulp. In the central and peripheral nervous systems, different neuronal groups showed different reaction intensities. In the endocrine system, ECRG4 immunoreaction was detected in the hypothalamic paraventricular and supraoptic nuclei, hypophysis, thyroid and parathyroid glands, adrenal zona glomerularis and medulla and Leydig cells, as well as in follicular and luteal cells of the ovary. In the literature, ECRG4 has been reported to inhibit cell proliferation and increase apoptosis in various cell types. It is down-regulated, frequently due to hypermethylation, in esophageal, prostate, breast and colon cancers, together with glioma (oncosuppressor function), although it is up-regulated in papillary thyroid cancer (oncogenic role). ECRG4 expression is also higher in non-proliferating cells of the lymphatic system. In conclusion, our identification of ECRG4 in many structures suggests the involvement of ECRG4 in the tumorigenesis of other organs and also the need for further research. In addition, on the basis of the location of ECRG4 in neurons and endocrine cells and the fact that it can be secreted, its role as a neurotransmitter/neuromodulator and endocrine factor must be examined in depth in the future.

\section{Introduction}

The Esophageal Cancer Related Gene 4 (ECRG4) is a tumour suppressor gene originally cloned and identified by Su et al. ${ }^{1}$ from normal human esophageal epithelium. It is located in chromosome 2q14.1-14.3 and contains 4 exons, spanning about $13 \mathrm{~kb}$ and having a corresponding cDNA of $772 \mathrm{bp}$. An initial bioinformatics analysis followed by biochemical characterisation demonstrated that ECRG4 encodes a peptide hormone which is processed and secreted. ${ }^{2}$ Further studies showed that the ECRG4 open reading frame encodes a 148 amino acid protein which can be cleaved into multiple peptides..$^{3-6}$ Apart from the full-length protein, the cleavage of a leader peptide yields the shorter protein called augurin, and further cleavage of the last carboxyl terminal 16 amino acids produces the so-called $\mathrm{C} \Delta 16$ augurin. The protein augurin is also cleaved by a furinlike process into two different peptides called ecilin and argilin, and argilin is cleaved into a $\mathrm{C} \Delta 16$ form. ${ }^{6}$ The sequences of human, mouse and rat ECRG4 are shown in Figure 1. ECRG4 contains a signal peptide sequence and a single putative pro-hormone cleavage site, followed by a long putative peptide which is highly conserved in mammals and fish. It also contains many aromatic amino acids and shows significant conservation in the sequence of the $\mathrm{N}$-terminal putative pro-hormone cleavage site.

ECRG4 processing by furin has been reported essential for inhibition of tumour cell (AtT20, SF767, 400-14) proliferation. ${ }^{5}$ ECRG4 also contains a porin/VDAC homology domain, a cell division cycle 45 homology domain, and an anaphase-promoting complex subunit 10 homology domain, indicating involvement in mitochondrial membrane permeability and the cell cycle. ${ }^{7}$ Anti-Flag immunocytochemistry following transfection of Flag-ECRG4 into rat pancreatic $\beta$-TC3 cells revealed co-location into dense core granules of the secretory pathway, and Western blotting of supernatant demonstrated secretion of ECRG4-derived peptides. ${ }^{2}$ Analysis of the subcellular location of ECRG4 by immunofluorescence in transfected cells has also revealed it in the mitochondria, Golgi apparatus and endoplasmic reticulum. ${ }^{3,7}$ In particular, ECRG4 is first 0-tyrosine-sulphated in the Golgi and then cleaved by furin just before or immediately after secretion along the constitutive secretory pathway. ${ }^{5}$
Correspondence: Prof. Raffaele De Caro, Section of Human Anatomy, Department of Molecular Medicine, University of Padua, Via A. Gabelli 65, 35121 Padova, Italy.

Tel. +39.049.8272327 - Fax: +39.049 .8272328 .

E-mail: rdecaro@unipd.it

Key words: Augurin, gene expression, immunohistochemistry, rat, ECRG4.

Acknowledgments: part of this study was carried out with grant IP2011 046671 from the Ministry of Science and Education, Poland. The authors are grateful to Anna Rambaldo for her skilfulltechnical assistance.

Contributions: all authors contributed to this work and approved the final version of the manuscript.

Conflict of interest: the authors declare no conflict of interest.

Received for publication: 13 November 2014.

Accepted for publication: 18 March 2015.

This work is licensed under a Creative Commons Attribution NonCommercial 3.0 License (CC BYNC 3.0).

(C) Copyright A. Porzionato et al., 2015 Licensee PAGEPress, Italy

European Journal of Histochemistry 2015; 59:2458 doi:10.4081/ejh.2015.2458

Recent studies have also shown that, after secretion, ECRG4 remains tethered in the cell surface of prostate (PC3) and kidney (HEK) epithelial cells ${ }^{8}$ and choroid plexus cells. ${ }^{6,9}$ Cell tethering is mediated by an $\mathrm{NH} 2$-terminus hydrophobic leader sequence, which enables trafficking to the surface. In some cells, such as PC3 and those of the choroid plexus, but not HEK, ECRG4 may be further processed, with release of cell surface proteins, to generate soluble peptides. ${ }^{6,8-10}$ In this sense, ECRG4 has been proposed to be more similar to cytokines like the tumour necrosis factor and growth factors like epidermal/transforming growth factors, i.e., cell membrane proteins which can be released by cell surface processing. ${ }^{8}$ Besides normal esophagus, ECRG4 has also been found by Northern blotting, RT-PCR and/or quantitative PCR (qPCR) to be expressed in many other tissues (brain, liver, kidney, heart, placenta, lung, pancreas, spleen, thymus, prostate, testis, bone marrow, skeletal muscle, cartilage, bladder, breast, corneal endothelium, and small and large intestine)..$^{1,7,11-16}$ Microarray analysis indicates the highest expression in the thyroid, pituitary, testis and adrenals in humans, and in adrenals, ovaries, digits, retina and trachea in mice. ${ }^{17}$ In the brain, its expression is highest in the olfactory bulbs, cerebellum, hypothalamus 
and amygdala, ${ }^{17}$ although further evaluation by qPCR showed the highest expression in the choroid plexus. ${ }^{6}$ In situ hybridisation in mice revealed prominent ECRG4 expression in the intermediate lobe of the pituitary, glomerular layer of the adrenal cortex, choroid plexus, and atrio-ventricular node of the heart, and on embryonic day 18.5 mouse adrenal cortex, choroid plexus and bone., ${ }^{2,6}$ Immunohistochemical analyses of ECRG4 expression have mainly been performed in the brain. In particular, it has been identified in neurons of the paraventricular and supraoptic nuclei and axonal projections into the neurohypophysis and median eminence. ${ }^{9,18}$ In rodents and humans, ECRG4 has been immunohistochemically identified in the ventricular side and secretory vesicles of choroid plexus cells, and immunoblotting has revealed it in cerebrospinal fluid as a 14-kDa band. ${ }^{6,9}$ In the developing brain of mouse embryo, the expression of ECRG4 has been found mainly located in the choroid plexus and, in rat, in ventricular ependymal cells. ${ }^{6}$ Other authors have also recently reported ECRG4 full-length $14 \mathrm{kDa}$ protein in mouse lung by immunoblotting and in type I alveolar cells by immunohistochemistry. ${ }^{16}$ The aim of the present study was to analyse ECRG4 expression in a wide series of normal rat tissues by qPCR and immunohistochemistry, in order to establish its expression profiles in the rat. A detailed review of the available literature about ECRG4 functions has also been performed.

\section{Materials and Methods}

\section{Materials}

Rat tissues were obtained from six 7-weekold intact rats of Wistar strain, three males and three females, kept under a 12-h light:12-h dark cycle (illumination onset at 8.00 a.m.) at $23^{\circ} \mathrm{C}$, and maintained on a standard diet and tap water ad libitum. Animals were sacrificed by decapitation. The study protocol was approved by the local Ethics Committee for Animal Studies. Sampled tissues are shown in Figure 2. For mRNA expression studies, tissues were immediately placed in RNA later (Qiagen, Hilden, Germany) and frozen at $80^{\circ} \mathrm{C}$. Tissues for immunohistochemistry were

\begin{tabular}{|c|c|c|c|c|c|}
\hline \multicolumn{3}{|c|}{ Signal peptide } & \multirow[b]{2}{*}{40} & \multirow[b]{2}{*}{50} & \multirow[b]{2}{*}{60} \\
\hline 10 & 20 & 30 & & & \\
\hline PARPAV & LALTGLALLL & LLCWGPGGIS & GNKLKLMLQK & REAPVPTKTK & VAVDENKAKE \\
\hline MGTSSARPAV & LALAGLALLL & LLCLGPGDVS & GNKLKKMLQK & REGPVPSKTN & VAVSEHTAKE \\
\hline MSTSSARPAV & LALÄGLALLL & LLCLGPDGIS & GNKLKKMLQK & REGPVPSKTN & VAVAENTAKE \\
\hline
\end{tabular}

Homo sapiens

Rattus norvegicus

Mus musculus

Homo sapiens

Rattus norvegicus

Mus musculus

\begin{tabular}{|c|c|c|c|c|c|}
\hline 70 & 80 & 90 & 100 & 110 & 120 \\
\hline FLGSLKRQKR & QLWDRTRPEV & QQWYQQFLYM & GFDEAKFEDD & ITYWLNRDRN & GHEYYGDYYQ \\
\hline FLGGLKRAKR & QLWDRTRPEV & QQWYQQFLYM & GFDEAKFEDD & VNYWLNRNQN & GHDYYGDYYQ \\
\hline FLGGLKRAKR & QLWDRTRPEV & QQWYQQFLYM & GFDEAKFEDD & VNYWLNRNRN & GHDYYGDYYQ \\
\hline 130 & 140 & 150 & 160 & 170 & 180 \\
\hline & FRHG & & & & \\
\hline HYDEDAAIG & PRSREGFRHG & SVNYDDY . . & & & $\ldots \ldots$ \\
\hline RHYDEDAAIG & PHSRESFRHG & ASVNYNDY . . & $\ldots \ldots \ldots$ & $\ldots \ldots \ldots$ & $\ldots \ldots \ldots$ \\
\hline
\end{tabular}

Figure 1. Amino acid sequences of human, mouse and rat ECRG4. Signal peptide is marked. Yellow, 100\% homology. Green, homology more than $50 \%$ but less than $100 \%$.
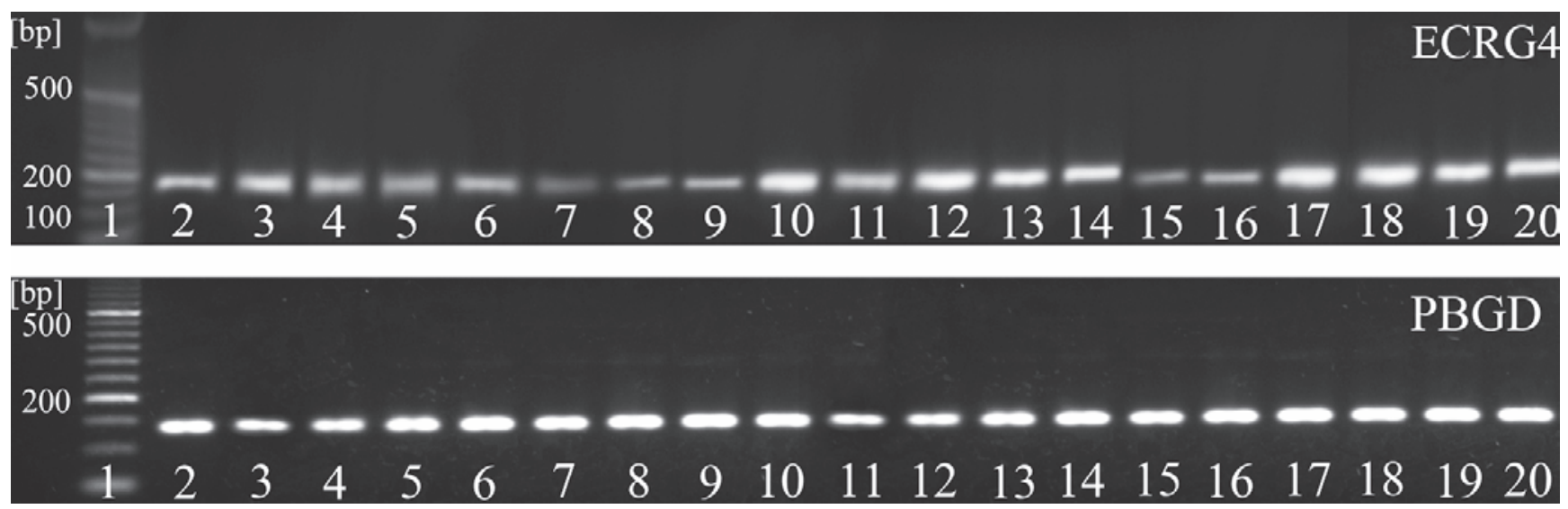

Figure 2. Ethidium bromide-stained $2 \%$ agarose gel showing specific product for expression of ECRG4 gene (upper panel) and reference gene (lower panel) in various tissues. 1, DNA molecular marker size; 2, esophagus; 3, stomach; 4, small intestine; 5, liver; 6, pancreas; 7 , lung; 8, skeletal muscle; 9 , heart; 10, uterus; 11, thymus; 12, spleen; 13, kidney; 14, urinary bladder; 15, brain; 16, hypothalamus; 17 , hypophysis; 18 , adrenal gland; 19 , testis; 20 , ovary. 
fixed in 10\% buffered formalin for $48 \mathrm{~h}$ and embedded in paraffin.

\section{Quantitative PCR (qPCR)}

The applied methods have already been described. ${ }^{19-28}$ Briefly, total RNA was extracted by the method with TRI REAGENT (Sigma) and purified on columns (Rneasy Mini Kit, Qiagen). mRNA was extracted from total RNA with the PolyATract ${ }^{\circledR}$ mRNA Isolation System III (Promega, Madison, WI), the amount of total mRNA was determined by measurement of optical density at $260 \mathrm{~nm}$, and purity was estimated by the $260 / 280 \mathrm{~nm}$ absorption ratio, which was consistently higher than 1.8 (NanoDrop spectrophotometer, Thermo Scientific, Milan, Italy). Reverse transcription was performed by AMV reverse transcriptase (Promega) with Oligo dT (PE Biosystems, Warrington, UK). Primers used for expression analysis experiments were designed by Primer 3 software (Whitehead Institute for Biomedical Research, Cambridge, MA, USA) (Table 1) and were purchased from the Laboratory of DNA Sequencing and Oligonucleotide Synthesis, Institute of Biochemistry and Biophysics, Polish Academy of Sciences, Warsaw. qPCR was performed by means of the lightcycler 2.0 instrument (Roche, Milan, Italy) with ver. 4.05 software. The SYBR green detection system was used with the above-mentioned primers. Each $20-\mu \mathrm{L}$ dose of the reaction mixture contained $4 \mu \mathrm{L}$ template cDNA (or standards, or control), $0.5 \mu \mathrm{M}$ of each gene-specific primer, and the previously determined optimal $\mathrm{MgCl} 2$ concentration $(3.5 \mu \mathrm{M}$ per reaction). The LightCycler FastStart DNA Master SYBR Green I mix (Roche) was used. The qPCR program included a 10-minute denaturation step to activate the Taq DNA polymerase, followed by three-step amplification: denaturation at $95^{\circ} \mathrm{C}$ for $10 \mathrm{~s}$, annealing at $56^{\circ} \mathrm{C}$ for $5 \mathrm{~s}$, and extension at $72^{\circ} \mathrm{C}$ for $10 \mathrm{~s}$. The specificity of reaction products was checked by determination of melting points $\left(0.1^{\circ} \mathrm{C} / \mathrm{s}\right.$ transition rate). ECRG4 gene expression was normalised to the $P B G D$ reference gene. Reaction products were separated on ethidium bromide containing $2 \%$ agarose gel and photographed in a transilluminator. qPCR efficiency was assessed by a serial dilution method. Specific bands from agarose gel were extracted by the
DNA gel extraction kit (Millipore, Milan, Italy), and the amount of extracted DNA was estimated spectrophotometrically. The extracted DNA was diluted (10-fold serial dilutions) in order to obtain standard curves for efficiency calculation. The applied version of LightCycler software (4.05.) allows evaluation of amplification efficiency plots.

\section{Immunohistochemistry}

Sections were hydrated gradually through decreasing concentrations of ethanol and then washed in deionised $\mathrm{H}_{2} \mathrm{O}$. Antigen unmasking was performed with $10 \mathrm{mM}$ sodium citrate buffer, $\mathrm{pH} 6.0$, in an oven at $96^{\circ} \mathrm{C}$ for $60 \mathrm{~min}$. This treatment allowed antigen retrieval without significant damage to the tissues; only in few cases was it necessary to repeat the procedure in further samples. The sections were incubated in $0.3 \%$ hydrogen peroxide for 10 min at room temperature, to remove endogenous peroxidase activity, and then in blocking serum (2\% normal goat serum) for $30 \mathrm{~min}$. Sections were incubated with primary rabbit polyclonal antibody anti-ECRG4 (HPA008546 C2orf40; Sigma Prestige Antibodies, St. Louis, M0, USA) and diluted 1:50 in PBS for $1 \mathrm{~h}$ at room temperature. The immunogen sequence for development of the polyclonal antibody consisted of the sequence 40-146 of the full-length human ECRG4. Thus, the above antibody does not distinguish between the various peptide forms which may be produced from the fulllength 148 amino acid-long ECRG4 protein. For this reason, we refer here to ECRG4 immunoreactivity, aware that different tissues or cells may show different peptides derived from ECRG4. The sections were then washed in PBS three times for $5 \mathrm{~min}$, incubated with anti-mouse/rabbit serum for $30 \mathrm{~min}$ (Cat. No. MP-7500; Vector Laboratories Inc., Burlingame, CA, USA), and developed in 3,3'diaminobenzidine (DAB, Sigma-Aldrich, Milan, Italy). Lastly, they were counterstained with haematoxylin. ECRG4 immunoreaction detected in human cerebellar Purkinje cells was used as a positive control, as recommended in the datasheet for the antibody. Negative controls were performed by omission of primary antibody. In addition, in order to further verify the immunohistochemical specificity of the reaction, absorption tests with ECRG4derived peptides comprising the above immunogen sequence (Prepro-Augurin 42-70 Human, Cat. no. 012-19, and Augurin Human 71-150, Cat. no. 012-25; Phoenix Pharmaceuticals, Burlingame, CA, USA) were also performed. Although competition tests were useful to confirm the specificity of ECRG4 immunoreactivity, they did not refer to immunoreactions to specific ECRG4-derived peptides, due to overlaps in their sequences, the length of the immunogen sequence and the polyclonality of the antibody.

Immunohistochemical staining for ECRG4 was evaluated by scanning whole tissue specimens under low-power magnification (X5), later confirmed under high-power magnification (X10, X20, X40). Immunohistochemical evaluation included number of positive cells, pattern of immunostaining (nuclear, cytoplasmic, nucleocytoplasmic) and staining intensity. Overall staining intensity was stratified as: -, absent; +/-, barely detectable; +, weak; ++, moderate; +++ , strong. ${ }^{29,30}$ Data for these studies are listed in Table 2.

\section{Results}

\section{qPCR}

Classic gel electrophoresis of the qPCR product reaction revealed the presence of ECRG4 mRNA in all tissues and organs studied: esophagus, stomach, small intestine, liver, pancreas, lung, skeletal muscle, heart, uterus, thymus, spleen, kidney, urinary bladder, brain, hypothalamus, adenohypophysis, adrenal gland, testis and ovary (Figure 2). We then applied $q P C R$ to study the relative expression levels of the ECRG4 gene. As shown in Figure 3, the highest levels of ECRG4 mRNA were found in esophagus, stomach, skeletal muscle, heart, uterus, urinary bladder and brain. In kidney, hypothalamus and adrenal gland, levels of ECRG4 mRNA were moderate, and the lowest expression levels were found in small intestine, liver, pancreas, lung, thymus, spleen, adenohypophysis, testis and ovary.

Table 1. qPCR primers of ECRG4 and PBGD (porphobilinogen deaminase). Oligonucleotide sequences for sense (S) and antisense (A) primers are shown.

\begin{tabular}{lccccc} 
cDNA & GenBank Accession number & Primer & Primer sequence $\left(5^{\prime}-3^{\prime}\right)$ & Position & PCR product sive (bp) \\
ECRG4 & XM_343562 & S & GACCTGTTCCATCAAAGAC & $169-187$ & 187 \\
& & A & AGCCAATAGTTGACATCATC & $336-355$ & \\
PBGD & NM 013168 & S & GAAAGACCCTGGAAACCTTG & $397-416$ & 148 \\
& & A & TGCTCATCCAGCTTCCTA & $526-544$ & \\
\hline
\end{tabular}




\section{Immunohistochemistry}

We found ECRG4 immunoreactivity in many tissues and organs, although expression levels differed among cell populations. As regards its intracellular location, ECRG4 immunoreaction was mainly found in the cytoplasm. Absorption tests eliminated immunostaining in all tissues (some examples are given in Supplementary Figure 1), except for some very faint diffused stains still visible in some sections.

\section{Respiratory system}

In tracheal epithelium, a few probably infiltrating cells with nuclear immunostaining were seen; bronchial and bronchiolar epithelial cells were negative (Figure 4A). No staining was seen in tracheal or bronchial chondrocytes. Bronchiolar smooth muscle cells (Reissesen membrane) were weakly immunopositive. In lung parenchyma, the great majority of pneumocytes were negative, although rare alveolar lining cells with weak/moderate cytoplasmic immunoreaction were found (Figure 4B).

\section{Muscles}

Skeletal (Figure 4C) and heart muscles (Figure 4D) showed moderate immunostaining. Smooth muscle cells of the gastrointestinal tract, urinary system and vessels were rather negative or showed only weak cytoplasmic immunostaining.

\section{Bone}

Osteoblasts, osteocytes and osteoclasts were mainly negative. Cells in the bone marrow were also negative.
Table 2. Expression of ECRG4-like immunoreactivity in normal rat tissues.

\begin{tabular}{|c|c|c|c|}
\hline lissues and organs & Cell types & Nuclear positivity & Cytoplasmic positivity \\
\hline \multicolumn{4}{|l|}{ Muscular tissues } \\
\hline Heart & Muscle cells & - & ++ \\
\hline Skeletal muscle & Muscle cells & - & ++ \\
\hline Smooth muscle & Muscle cells & - & $+/-$ \\
\hline \multirow[t]{4}{*}{ Bone } & Osteoblasts & - & - \\
\hline & Osteoclasts & - & - \\
\hline & Marrow & - & - \\
\hline & Megakaryocytes & - & - \\
\hline \multicolumn{4}{|l|}{ Digestive system } \\
\hline Esophagus & Epithelium & - & ++ \\
\hline \multirow[t]{2}{*}{ Stomach } & Superficial epithelium & - & - \\
\hline & Base of glands & - & + \\
\hline Small intestine & Epithelium & - & - \\
\hline Colon & Epithelium & - & - \\
\hline Liver & Hepatocytes & - & ++ \\
\hline \multirow[t]{2}{*}{ Exocrine pancreas } & Acinar epithelium & - & + \\
\hline & Ductal epithelium & - & - \\
\hline \multicolumn{4}{|l|}{ Respiratory system } \\
\hline & Alveolar epithelium & - & - \\
\hline & Bronchial epithelium & - & - \\
\hline \multicolumn{4}{|l|}{ Urinary system } \\
\hline \multirow[t]{2}{*}{ Kidney } & Renal corpuscles & - & - \\
\hline & Tubular epithelium & - & - \\
\hline Bladder & Epithelium & - & - \\
\hline \multicolumn{4}{|l|}{ Male reproductive system } \\
\hline \multirow[t]{5}{*}{ Testicle } & Spermatogonias & - & - \\
\hline & Spermatocytes & - & - \\
\hline & Sertoli cells & - & - \\
\hline & Leydig cells & - & ++ \\
\hline & Residual bodies & - & ++ \\
\hline Epididymis & Epithelium & - & - \\
\hline Seminal vesicles & Epithelium & - & - \\
\hline Prostate ventral lobe & Epithelium & $+/-$ & $+/-$ \\
\hline
\end{tabular}

To be continued on next page

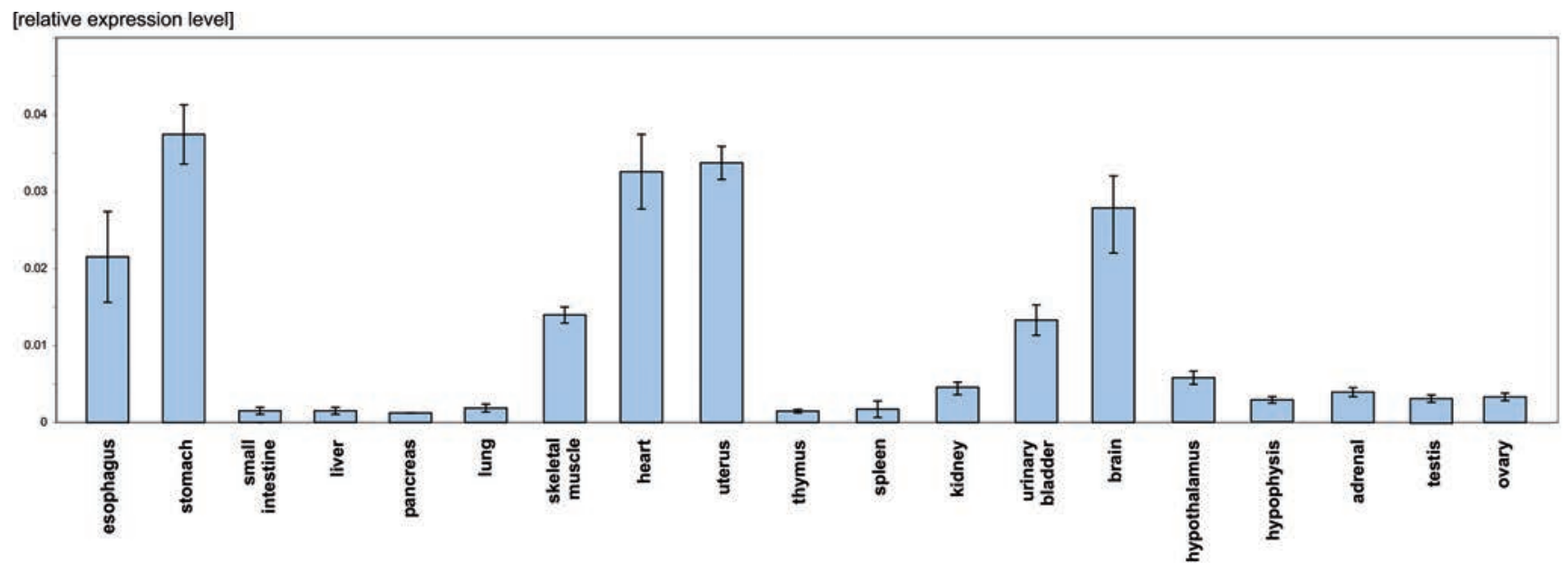

Figure 3. Relative mRNA expression level of ECRG4 in various tissues. Bar plots: expression \pm SE. Expression profile calculated in relation to $P B G D$ reference gene. In each group, $\mathrm{n}=3$. 


\section{Cartilage}

Chondrocytes were mainly negative.

\section{Lymphatic tissues}

In lymph nodes (Figure $5 \mathrm{~A}-\mathrm{B}$ ), most of the cortical cells were negative, whereas the medulla cells showed moderate/strong cytoplasmic immunoreactivity.The epithelial cells of the thymus were negative in both medullary and cortical compartments, Hassal's corpuscles were also negative. Lymphatic cells were mainly negative, but some quite numerous groups of cells showing moderate/strong cytoplasmic immunoreactivity were also visible, mainly in the cortical compartment (Figure $5 \mathrm{C})$. In the spleen, white pulp cells were mainly negative, whereas those in the red pulp showed moderate or strong cytoplasmic immunostaining (Figure 5D). Aggregates of lymphocytes along the alimentary canal were mainly negative, with a few cells showing moderate cytoplasmic staining.

\section{Digestive system}

In the salivary glands, ductal and acinar epithelia were mainly negative, as were the connective septa (Figure 6A). The esophageal epithelium showed moderate cytoplasmic immunostaining, mainly in the superficial layers (Figure 6B). The lamina propria and submucosal layer were negative. Smooth muscle cells of the muscularis mucosae and muscle layer showed weak cytoplasmic staining. In the stomach, epithelial cells were mainly negative, although some cells in the gastric gland bases showed moderate cytoplasmic staining (Figure 6C). In the small intestine, epithelial cells were negative, but some cells showing strong cytoplasmic immunostaining were visible in the lamina propria (Figure 6D). Hepatocytes showed moderate cytoplasmic staining without nuclear immunoreaction. Connective tissue in the portal spaces was negative. Sinusoidal lining cells, portal tracts, terminal hepatic venules and hepatic arterioles were negative. Bile ducts were usually negative (Figure 6E). In the exocrine pancreas, weak cytoplasmic immunoreaction was found in some acinar secretory cells. Connective septa were negative (Figure 6F).

\section{Urinary system}

Renal corpuscles and tubular epithelium were usually negative or weakly positive. The surrounding fibrous stroma was negative, although rare cells showing sometimes strong cytoplasmic immunoreaction were detectable (Figure 7A). Ureter and bladder epithelium (Figure 7B) was mainly negative, whereas muscle layers showed weak/moderate positivity.

\section{Female germinal system}

In the ovary (Figure 7C-D), granulosa cells frequently showed moderate cytoplasmic immunostaining. Thecal cells showed weak cytoplasmic staining. The corpora lutea sometimes showed quite strong cytoplasmic immunostaining, mainly in their central parts. Interstitial gland cells showed weak cytoplasmic immunostaining. Stroma was mainly negative. The epithelial cells of the oviducts (Figure 7E) showed moderate or strong cytoplasmic immunoreactivity, whereas stroma was negative and muscle layers only showed weak cytoplasmic staining. Endometrial and vaginal epithelium showed weak cytoplasmic immunostaining. The lamina propria was negative.

\section{Male germinal system}

In the testis, spermatogonias, spermatocytes and spermatids, together with Sertoli cells, did not immunostain. Conversely, Leydig cells showed moderate/strong cytoplasmic positivity (Figure 7F). The epithelia of epididymis

Table 2. Continued from previous page.

Tissues and organs Cell types Nuclear positivity Cytoplasmic positivity

Female reproductive system

Ovary

viduct

Uterus

Vagina

Endocrine glands

Hypophysis

Thyroid

Parathyroid

Adrenal gland

Adrenal gland

$\begin{array}{cc} & \text { Medulla } \\ \text { Ganglionic cells } \\ \text { Islets of Langerhans } & \text { Langerhans cells }\end{array}$

Lymphatic system

Thymus

Epithelial cells

Lymphatic cells, Cortex

Lymphatic cells, Medulla

Lymph node Lymphatic nodules - germinal centre

Deep cortex

Medullary region

Spleen

Red pulp

White pulp

\begin{tabular}{|c|c|c|c|}
\hline \multirow{2}{*}{\multicolumn{4}{|c|}{ Nervous system }} \\
\hline & & & \\
\hline \multirow[t]{2}{*}{ Brain cortex } & Neurons & - & $+/-$ \\
\hline & Glia & - & - \\
\hline \multirow[t]{3}{*}{ Cerebellum } & Purkinje cells & - & ++ \\
\hline & Granular and molecular layers & - & $+/-$ \\
\hline & Glia & - & - \\
\hline \multirow[t]{2}{*}{ Brainstem } & Neurons & - & ++ \\
\hline & Glia & - & - \\
\hline Trigeminal gan & Neurons & - & ++ \\
\hline Superior cervi & Neurons & - & ++ \\
\hline
\end{tabular}

Eye

Retina

Cornea

Ciliary corpus weak; ++ , moderate; +++ , strong. 
and seminal vesicles were mainly negative. Prostate also showed quite variable immunoreaction.

\section{Endocrine glands}

In the hypothalamus, neurons of the supraoptic (Figure 8A) and paraventricular nuclei showed moderate cytoplasmic immunoreactivity; the other hypothalamic nuclei were mainly negative. In the adenohypophysis, some cells showed weak cytoplasmic immunostaining; others did not immunostain. In the neurohypophysis, fibres and pituicytes showed weak/moderate immunostaining. The cells of the pars intermedia showed weak cytoplasmic immunoreaction. In the thyroid, follicular epithelial cells showed heterogeneous staining. In some follicles, epithelial cells showed weak/moderate cytoplasmic staining; others did not immunostain. Parafollicular cells also showed weak cytoplasmic immunoreactivity (Figure 8B). The principal cells of parathyroid glands showed weak cytoplasmic immunostaining. Adrenal cortex cells showed moderate ECRG4 cytoplasmic immunostaining in the zona glomerularis (ZG), while zona fasciculata-reticularis (ZF/R) was mainly negative. Adrenal medullary and ganglionic cells showed moderate cytoplasmic positivity (Figure $8 \mathrm{C}$-D). The cells of the islets of Langerhans did not show ECRG4 immunostaining (Figure 6F).

\section{Nervous system and eye}

In the central nervous system, some neuronal groups showed moderate cytoplasmic immunostaining, whereas others were negative. Glial cells were usually negative, except for ventricular ependymal cells and choroid plexus epithelial cells, which showed moderate immunoreactivity. In the brain cortex and hippocampus (CA1, CA2, CA3, CA4, dorsal and ventral blades of the dentate gyrus), neurons were negative or showed weak cytoplasmic immunoreactivity (Figure 9A). In the cerebellar cortex, Purkinje cells showed moderate cytoplasmic immunostaining. In the granular and molecular layers, most cells were negative, although some showing cytoplasmic immunostaining were also detected (Figure 9B). In the brainstem, various nuclei showed different percentages of immunostained neurons and different staining intensity, e.g., the olivary complex showed quite high percentages of immunoreactivity (Figure 9C). As regards the peripheral nervous system, the ganglionic cells of both trigeminal (Figure 9D) and superior cervical ganglia showed quite strong cytoplasmic immunoreaction. The structures of the retina, cornea and ciliary body were mainly negative.
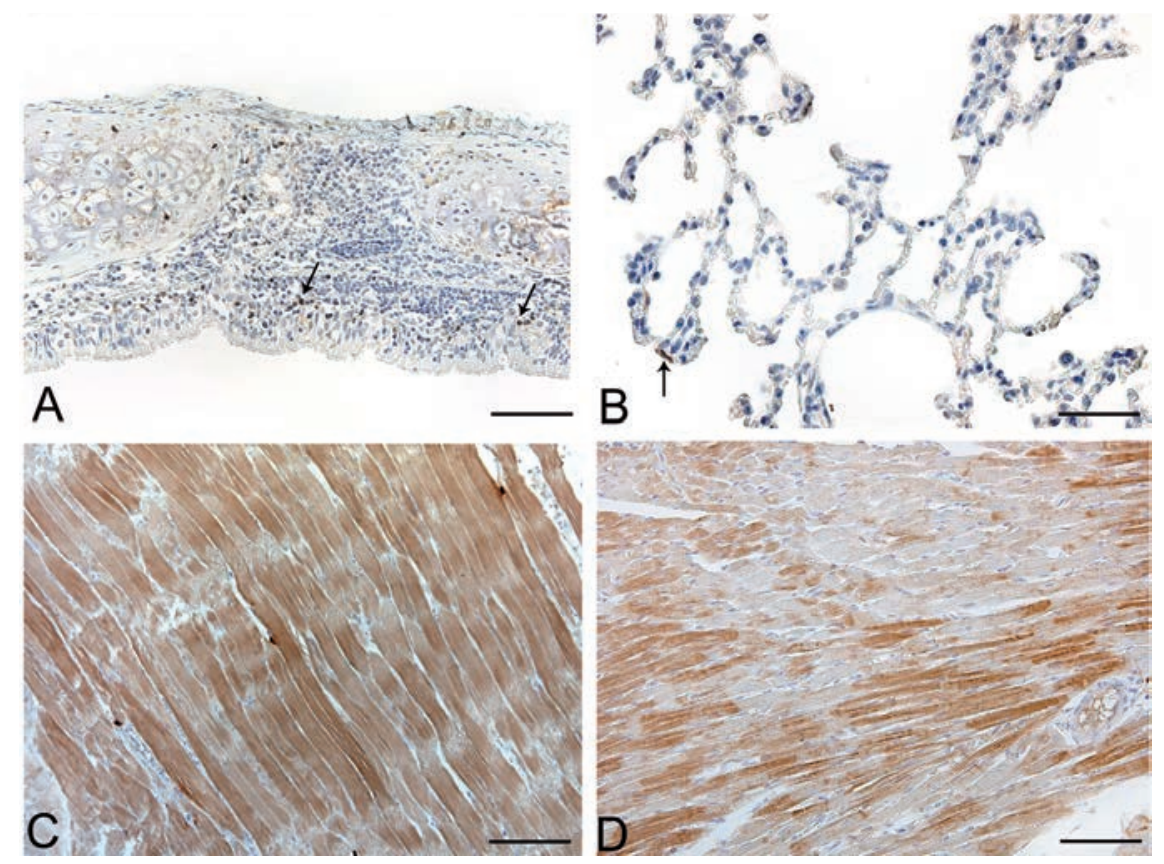

Figure 4. Anti-ECRG4 immunohistochemical staining of rat normal tissues. A) Trachea; positive immune cells (arrows) visible in tracheal mucosa; epithelial cells are mainly negative. B) Lung parenchyma; most cells are negative, with rare type I pneumocytes (arrow) immunostained. C) skeletal muscle. Diffuse moderate immunostaining of skeletal muscle fibers. D) Heart; groups of immunopositive heart muscle fibers interspersed with negative ones. Scale bars: A, D) $75 \mu \mathrm{m}$; C) $150 \mu \mathrm{m}$; B) $37.5 \mu \mathrm{m}$.
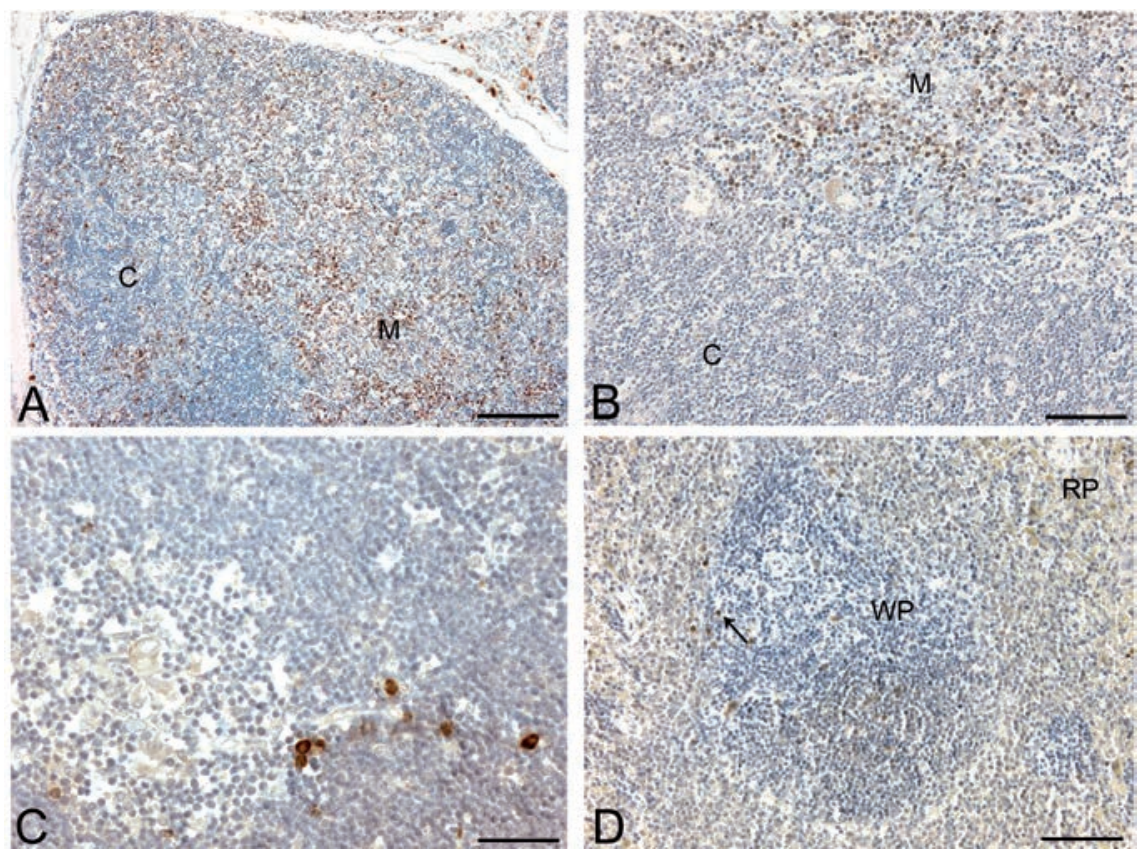

Figure 5. Anti-ECRG4 immunohistochemical staining of rat lymphatic system. A-B) Lymph node; in lymph node medulla $(M)$, immunostained cells are more numerous than in cortex (C). C) Thymus; most cells are negative but some immune cells show moderate/strong immunoreactivity. D) Spleen; some positive immune cells (arrows) are visible in both white (WP) and red (RP) pulp. Scale bars: A, C, D) $75 \mu \mathrm{m}$; B) $37.5 \mu \mathrm{m}$. 


\section{Discussion}

In this work, we carried out extensive analysis of ECRG4 expression in many rat tissues by means of qPCR and immunohistochemistry. We discuss our results on the basis of a review of literature data on ECRG4 expression and functions.

\section{Esophagus and ECRG4 role in tumorigenesis}

One of the first organs studied for the ECRG4 expression and its possible role in tumorigenesis was the esophagus, which usually reveals ECRG4 immunostaining in its epithelium. The ECRG4 gene has been suggested to be involved in esophageal tumorigenesis, as ECRG4 mRNA and protein are downregulated in esophageal squamous cell carcinoma (ESCC) $)^{1,11,31-34}$ and esophageal cancer cell lines (NEC, EC109 and EC9706). ${ }^{31-36}$ No somatic mutations have been found in the ECRG4 gene in esophageal cancer tissues, ${ }^{33,35}$ although hypermethylation of a 5' CpG island in its promoter region is one of the main silencing mechanisms in esophageal cancer cell lines. ${ }^{31,33,35}$ Low ECRG4 mRNA and protein levels have been found to correlate with primary tumour size, regional lymph node metastasis and clinico-pathologic stage. ${ }^{32,33}$ They are also associated with significantly shorter survival, ECRG4 expression being an independent prognostic factor for ESCC patients. ${ }^{32,33}$ Transfection of ECRG4 gene into ESCC cells inhibits cell proliferation, colony formation and anchorage-independent growth in soft agar, and blocks cell cycle progression and reduces tumour growth in vivo after subcutaneous injection in nude mice. ${ }^{33}$ As regards the molecular mechanisms involved, restoration of ECRG4 expression in ESCC inhibits NF-kB expression and nuclear translocation and attenuates $\mathrm{NK}-\mathrm{kB}$ target gene $\mathrm{COX}-2$ expression. ${ }^{33}$ ECRG4 has been reported to interact directly with $E C R G 1$, in both binding affinity assays in vitro and co-immunoprecipitation assays in vivo. ECRG4 and ECRG1 co-expression further increases p21 expression, reinforces cell cycle G1 phase block and inhibits cell proliferation, strongly suggesting functional interactions between the proteins. ${ }^{35}$ Inverse correlation has been reported between ECRG4 expression and the Ki-67 labelling index in esophageal squamous cell carcinoma. ${ }^{34}$

\section{Expression and function of ECRG4 in other epithelial tissues}

In this study we identified ECRG4 expression not only in esophageal epithelium but also in other epithelial cells of the digestive system, such as the cells of the bases of gastric glands, intestinal epithelium, hepatocytes and pancreatic exocrine cells. ECRG4 immunostaining was identified in the epithelial structures of the male and female reproductive systems, such as ovary follicles, oviduct, uterus, vagina and prostate. Immunostaining in the respiratory and urinary systems was more variable. ECRG4 has previously been identified in the epidermis, dermis and hair follicles of mouse skin. ${ }^{37}$ Expression of ECRG4 in many different types of epithelia (although not in all of them) obviously indicates its probable role. For some of the above epithelia, literature data indicate a role for ECRG4 in proliferation/ tumorigenesis, similar to what has already been shown for the esophagus.

ECRG4 has been reported to play a role in cancers other than esophageal ones. It is down-regulated not only in prostate cancer, ${ }^{38,39}$ breast cancer ${ }^{40-41}$ and colon carcinoma, ${ }^{3}$ but also in many human tumour epithelial cell lines (oral, esophageal, gastric, colon, lung, breast, cervical and renal cancers) ${ }^{31,34,41} \mathrm{CpG}$ site hypermethylation is considered to be the main mechanism of down-regulation in these neoplasms. It is significantly associated with prostate, ${ }^{38,39}$ colorectal, $^{3,42}$ gastric $^{43}$ and breast ${ }^{41}$ cancers. ECRG4 hypermethylation has been reported for cell lines from colorectal, hepatocellular and breast carcinoma.,31 However, other regulatory mechanisms have also been suggested, as demethylating treatment was reported not to recoup ECRG4 expression in some prostate cell lines. ${ }^{39}$

ECRG4 is involved in the proliferation and
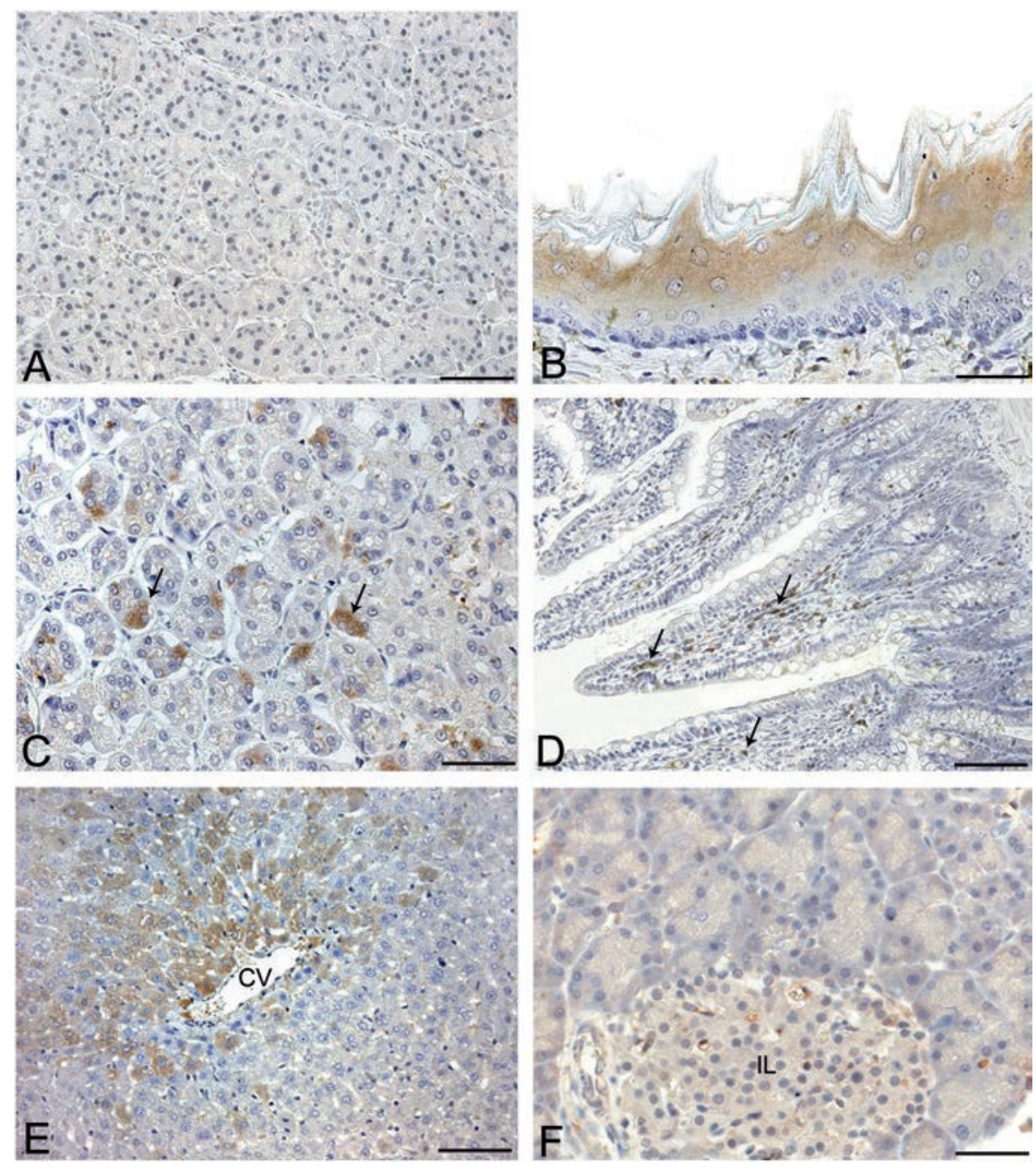

Figure 6. Anti-ECRG4 immunohistochemical staining of rat digestive system. A) Salivary gland; acinar and ductal epithelia are negative. B) Esophagus; moderate cytoplasmic immunostaining is appreciable in superficial layers. C) Stomach; in this slide, gastric glands are transversally cut and show moderate cytoplasmic immunoreaction in some epithelial cells (arrows). D) Small bowel; epithelial cells are mainly negative but ECRG4 positive immune cells are visible in lamina propria. E) Liver; groups of hepatocytes around centrilobular vein (CV) show moderate cytoplasmic immunostaining. F) Pancreas; exocrine acinar cells and cells of islets of Langerhans (IL) are mainly negative. Scale bars: A, C, F) $37.5 \mu \mathrm{m}$ : D, E) $75 \mu \mathrm{m}$. 
apoptosis of these epithelial types. Transfection of ECRG4 or exposure to ECRG4containing medium reduces the proliferation and cell viability of colorectal cell lines. ${ }^{3}$ Jurkat and 293T cells transfected with ECRG4 have been reported to show a significantly slower growth rate. ${ }^{34}$ Over-expression of ECRG4 into squamous cell carcinoma of the head and neck M2 cell line inhibits cell proliferation and promotes cell cycle arrest and apoptosis, together with Bax up-regulation and Bcl-2 and Cyclin A down-regulation. It also suppresses the growth rate and metastasis of tumor xenografts in nude mice. ${ }^{44}$ Restoration of ECRG4 expression in breast cancer cell lines by retroviral transduction decreases proliferation rate, migration and invasion of cells; conversely, ECRG4 knock-down shows the opposite effect in those breast cancer cell lines which do not show suppression of ECRG4 expression by hypermethylation. ${ }^{41}$ Reduction of cell proliferation by ECRG4 has been found to be due to mitotic inhibition by modulation of genes such as ubiquitin-conjugating enzyme E2C. ${ }^{41}$ Decreased cell proliferation has been reported in human lung epithelial cells in response to ECRG4 over-expression. ${ }^{16}$

Some clinical data have been published on the prognostic significance of ECRG4 expression. In prostate cancer, for instance, it is associated with Prostate-Specific Antigen recurrence. ${ }^{38}$ In breast cancer, ECRG4 expression is higher in neoplasms showing earlier stage, smaller size, negative axillary lymph node status, lower grade and normal-like subtype, and less risk of distant metastasis. Down-regulation of this gene is associated with reduced disease-free and overall survival. ${ }^{40,41}$ ECRG4 hypermethylation is higher in stages III+IV of gastric cancer than in stages I+II..$^{43}$ The role of ECRG4 has been investigated with reference to chemotherapeutic sensitivity. A human gastric cell line (SGC-7901) with tetracyclineinducible ECRG4 expression has been established and ECRG4 over-expression has been shown to increase apoptosis and inhibit growth in response to 5 -fluorouracil. ${ }^{45}$

Our study also showed ECRG4 expression in other epithelial types, not yet fully examined as regards their possible involvement in tumorigenesis, such as hepatocytes, pancreatic cells, and epithelial cells of the female reproductive system. Possible changes in ECRG4 expression must also be examined in the case of inflammatory and injury responses.

\section{Nervous system}

In the literature, ECRG4 expression has been identified in the brain by RT-PCR, ${ }^{1,11}$ in the choroid plexus by in situ hybridisation and immunohistochemistry ${ }^{2,6}$ and in the paraventricular and supraoptic nuclei by immunohistochemistry. ${ }^{9,18}$ Our immunohistochemical analysis confirmed the above findings, but also identified ECRG4 expression in the neurons of many other central and peripheral nervous structures. In the central nervous system, some nuclei showed high percentages of positivity and strong immunostaining, whereas others were negative. Proper mapping of the structures of the nervous system will be necessary to evaluate exactly in which nervous structures ECRG4 expression is higher. However, our analysis revealed higher ECRG4 expression in some neuronal groups of the brainstem, cerebellum and peripheral ganglia, and lower percentages of positivity in the cerebral cortex. Among brainstem nuclei, the infe-
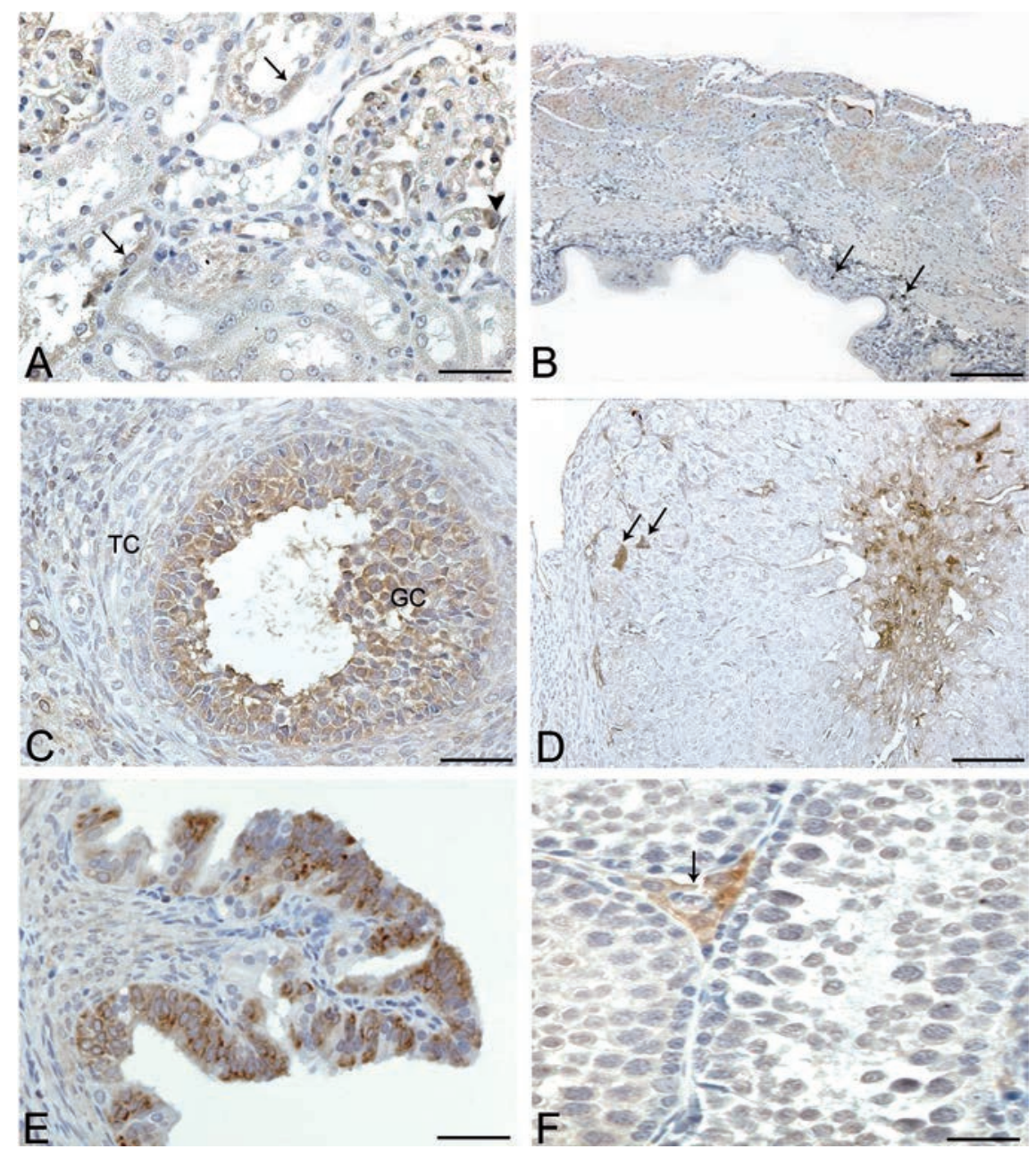

Figure 7. Anti-ECRG4 immunohistochemical staining of rat genitourinary system. A) Kidney; some tubular and glomerular epithelial cells show faint or moderate immunostaining, although most cells are negative. B) Urinary bladder; faint immunoreactivity of external portions of detrusor muscle; positive immune cells (arrows) also visible in mucosal layer. C) Ovarian secondary follicle; granulosa cells show diffuse cytoplasmic immunostaining; thecal cells are negative. D) Corpus luteum; quite strong, diffuse immunostaining is appreciable in centre, and some isolated cells (arrows) with strong ECRG4 immunostaining also appear in periphery of corpus luteum. E) Oviduct; intense, selective cytoplasmic immunostaining visible in epithelium; lamina propria is negative. F) Testis; Leydig cells (arrow) show selective cytoplasmic positivity; germinal epithelium of adjacent seminifer tubuli is negative. Scale bars: A, D, E, F) $37.5 \mu \mathrm{m}$; B) $150 \mu \mathrm{m}$; C); $75 \mu \mathrm{m}$. 
inversely correlated with ECRG4 expression. ${ }^{46}$ ECRG4 has been suggested to be an injury response gene in the central nervous system. A cortical lesion model in rats showed a significant decrease in the content of ECRG4 protein and mRNA (through immunohistochemistry and hybridisation in situ, respectively) in choroid plexus cells. This process lasted some days, and was interpreted as release of ECRG4 from the cell surface into the cerebrospinal fluid and subsequent decrease in ECRG4 expression throughout the proliferative phase of injury. Similar changes were not noted in the supraoptic nucleus. ${ }^{69}$ The injury response in the central nervous system involves proliferation of neural stem/progenitor cells. Interestingly, ECRG4 over-expression through intracerebroventricular injection of adenovirus vectors containing the transgene ECRG4 significantly reduces the number of BrdU positive cells in the subventricular zone, together with suppression of nestin staining. ${ }^{6}$ The possible role of ECRG4 in controlling cell proliferation in the central nervous system has also been studied as regards brain development. Functional ECRG4 knock-down in developing zebrafish increases cell proliferation of GFAP-positive cells at the ventricular surface and produces severe defects, including a ventricular hydrocephalus-like edema phenotype. ${ }^{6}$

ECRG4 has been suggested to be a secreted inducer of cell senescence in the central nervous system. Senescent mouse oligodendrocyte precursor cells show increased expression of ECRG4 and transfection of the central glia 4 cell line with an ECRG4 expression vector induces expression of senescence-associated acidic $\beta$-galactosidase, G1 arrest, dephosphorylation of $\mathrm{Rb}$, and decreased expression of cyclins D1 and D3. The secreted form of ECRG4 is present in the culture medium of senescent oligodendrocyte precursor cells, and the addition of recombinant mouse ECRG4 induces senescence of mouse oligodendrocyte precursor cells and neural progenitor cells of the dentate gyrus. ECRG4 expression is higher in some cell populations of aged mouse brain, such as oligodendrocyte precursor cells in the corpus callosum, neural progenitor cells in the subgranular zone of the dentate gyrus, hippocampal granule cells, Purkinjie cells and NeuN+ brainstem cells. ${ }^{4}$ It is also intriguing that ECRG4 is up-regulated in the hippocampus of a mouse model of Alzheimer's disease, i.e., transgenic mice over-express human Tau23 protein. ${ }^{47}$ Of particular interest are our findings about ECRG4 expression in the peripheral nervous system. The structures showing higher percentages of positivity and staining intensity were the trigeminal and superior cervical ganglia. It would be interesting in the future to evaluate the possible involvement of ECRG4 in injury responses of
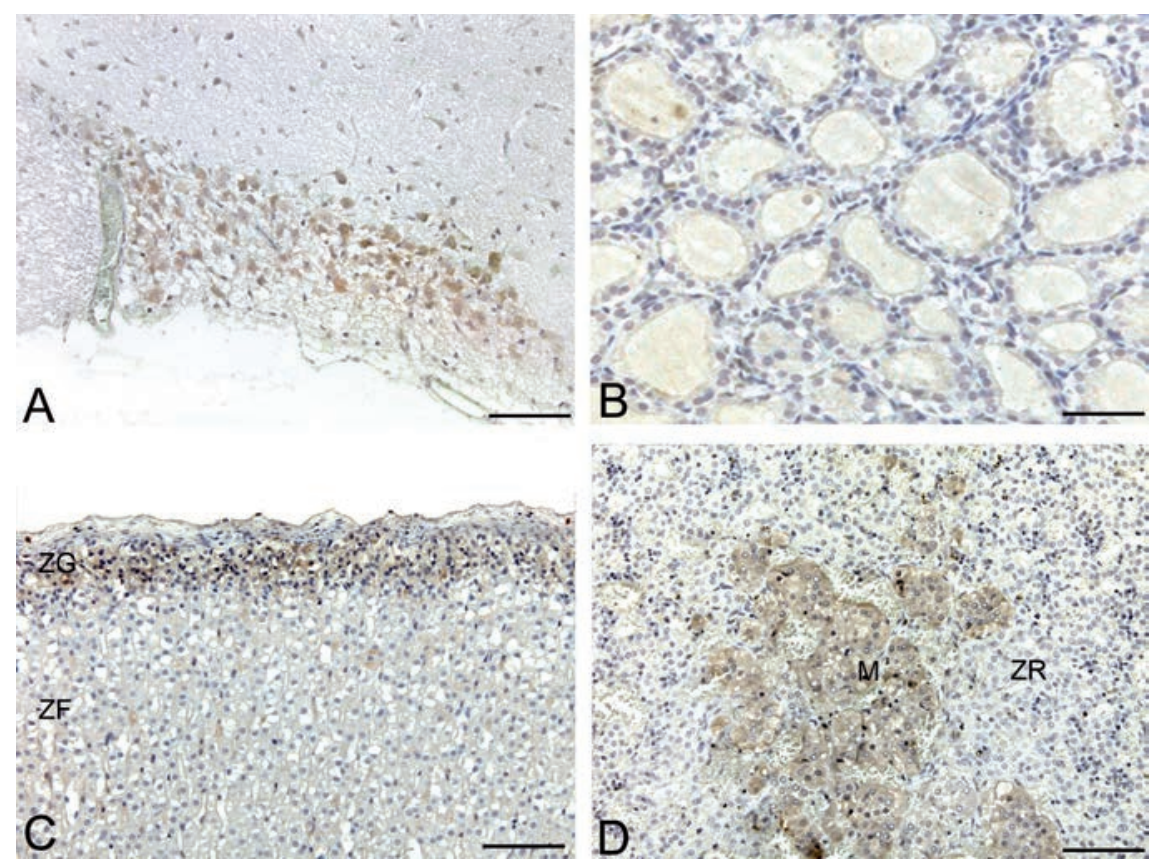

Figure 8. Anti-ECRG4 immunohistochemical staining of rat endocrine tissues. A) Supraoptic nucleus; note moderate cytoplasmic immunoreaction of neurons. B) Thyroid gland; negativity or faint immunoreaction of follicular epithelial cells. C) Adrenal cortex; note diffuse positivity of zona glomerularis, together with negativity of zona fasciculata. D) Adrenal medulla; appreciable and diffuse cytoplasmic positivity of medullary cells (M), together with negativity of zona reticularis of adrenal cortex. Scale bars: $75 \mu \mathrm{m}$.
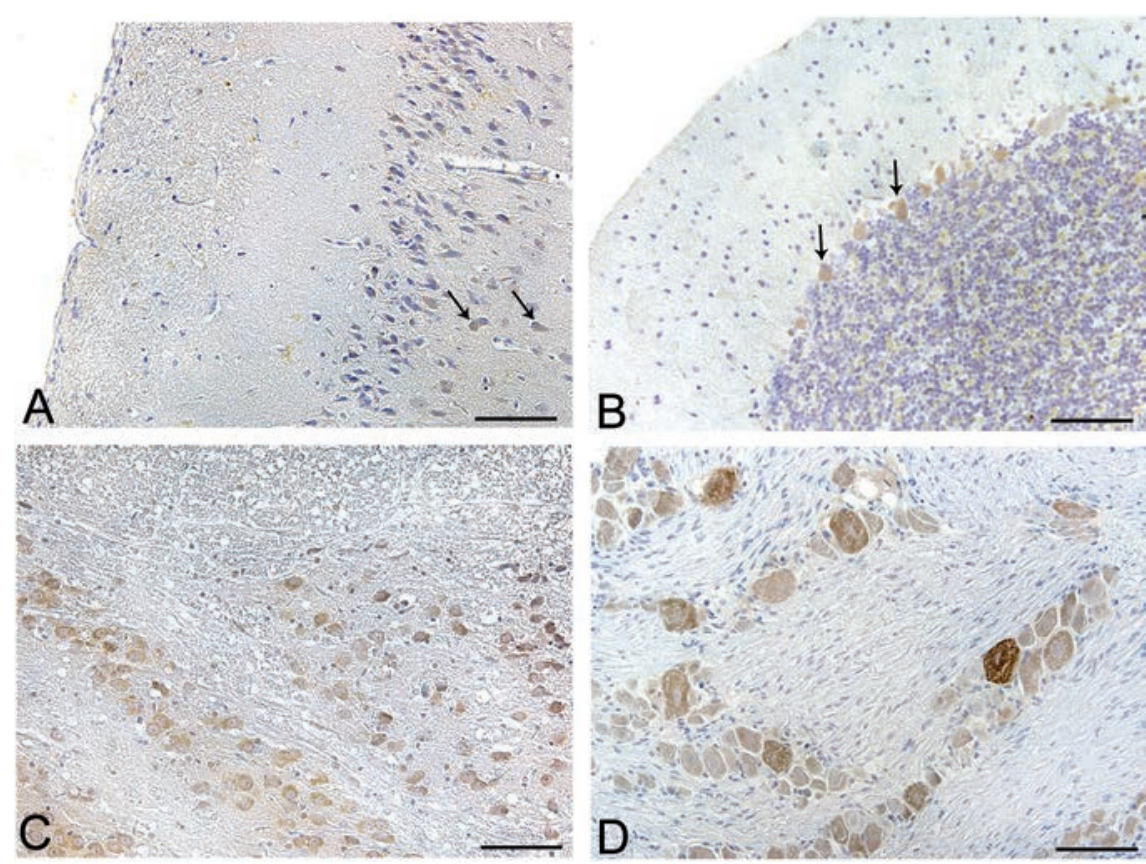

Figure 9. Anti-ECRG4 immunohistochemical staining of rat nervous system. A) Cerebral cortex; both positive (arrows) and negative neurons are present. B) Cerebellar cortex; note positivity of Purkinje cells (arrows). C) Inferior olivary nucleus; note ECRG4 immunostaining of large neurons of nucleus. D) Trigeminal ganglion; ganglion neurons are positive; nerve fibres and support cells are negative. Scale bars: $75 \mu \mathrm{m}$. 
peripheral nerves.

In the present work, we found ECRG4 expression in many neuronal populations of both the central and peripheral nervous systems, suggesting that ECRG4 also plays a role as neuromodulator. This possible function has not yet been experimentally studied but will certainly be a field for further investigation, partly due to the intriguing neuroendocrine effects of ECRG4-derived peptides. ${ }^{48}$

\section{Endocrine system}

As regards endocrine tissues, in the literature ECRG4 expression has been identified by in situ hybridisation in mouse intermediate lobe of the pituitary and glomerular layer of the adrenal cortex. ${ }^{2}$ The present analysis by qPCR confirmed previous data ${ }^{1,17}$ on ECRG4 expression in all endocrine glands. Our immunohistochemical analysis located ECRG4 mainly in the hypothalamic supraoptic and paraventricular nuclei, adrenal ZG and medulla, Leydig cells, and the follicular and luteal cells of the ovary. Anti-ECRG4 immunostaining was less intense in the hypophysis, thyroid and parathyroid glands. Although immunohistochemistry confirmed ECRG4 expression in all endocrine tissues in which qPCR identified ECRG4 mRNA, anti-ECRG4 immunohistochemical intensity did not perfectly correlate with qPCR results, probably due to post-transcriptional mechanisms in the regulation of ECRG4 expression. The presence of ECRG4 in many different endocrine cells and its capacity to be secreted suggest a role in the modulation of various endocrine functions, as already described for other neuropeptides, with particular reference to the adrenal gland. ${ }^{49-55}$

There are few functional data available at present about the role of ECRG4 in the endocrine system. Its expression in the supraoptic and paraventricular nuclei (9,18 and our results) support the hypothesis of ECRG4 involvement in fluid homeostasis and behaviour control. This was confirmed by a later study showing that, in the rat, injections of a synthetic fragment of human augurin (corresponding to amino acids 71-148 of ECRG4 protein) into the third cerebral ventricle or into the paraventricular nucleus increase plasma ACTH and corticosterone, without changes in the other hypothalamo-pituitary axis hormones, and these effects are blocked by pretreatment with a CRF receptor antagonist. Incubation of hypothalamic explants with augurin has also been reported to increase the release of CRF and AVP significantly. ${ }^{48}$ Thus, augurin (and possibly other peptides derived from ECRG4 protein) could be added to the long list of neuropeptides which play a double role in modulating endocrine and nervous functions. The quite specific location of ECRG4 in ZG and adrenal medulla also suggests its involvement in modulation of the production of mineralcorticoids and catecholamines. In male and female gonads, ECRG4 immunostaining was also mainly located in steroid-secreting cells. Further analyses will be necessary to evaluate the role of this protein in the endocrine functions of these organs. Lastly, we must stress that the only report on ECRG4 involvement in endocrine tumorigenesis is the recent paper by Chen et al., ${ }^{15}$ examining papillary thyroid carcinoma. Through qPCR and immunohistochemistry, the levels of ECRG4 mRNA and protein are reported to be up-regulated in papillary thyroid cancer tissues with respect to matched non-tumour samples. Tumour samples also showed lower methylation frequency than paired controls. Transfection of human papillary thyroid cancer cell lines (W3 and K1) for up-regulation of ECRG4 has been reported to promote cell proliferation activity and cell cycle transition from G1 to G2, in the absence of changes in apoptosis rate. ${ }^{15}$ This work is particularly important, as this is the first time that an oncogenic role has been reported for ECRG4, unlike the oncosuppressor function reported for most cancers previously studied. This means that ECRG4 may also play a role in the tumorigenesis of some tissues in which ECRG4 expression is not normally evident.

\section{Muscles and cartilage}

As regards other non-endocrine and non-nervous tissues and cells, we found ECRG4 expression, although quite moderate, in heart muscle cells and not only in the atrioventricular node as reported by Mirabeau et al., ${ }^{2}$ indicating the greater sensitivity of immunohistochemical analysis. Apart from heart muscle cells, ECRG4 was also identified in skeletal and, to a lesser extent, in smooth muscle cells. ECRG4 is highly expressed in developing cartilage; its expression is low in undifferentiated mesenchymal cells, but then increases in proliferating chondrocytes and decreases during hypertrophic maturation. ECRG4 expression is decreased in human and experimental osteoarthritic cartilages. ${ }^{56}$ However, its ectopic expression or exogenous administration has been reported not to affect the chondrogenesis of mesenchymal cells, hypertrophic maturation of chondrocytes or dedifferentiation of differentiated chondrocytes, although its ectopic expression does reduce the proliferation of primary-culture chondrocytes. ${ }^{56}$ Analysis of gene transcript expression has recently suggested a potential role for ECRG4 also in chordoma tumorigenesis. ${ }^{57}$

\section{Expression and role of ECRG4 in the immune system}

In the recent literature, many data have emerged regarding the role played by ECRG4 in inflammation and the immune response. qPCR has previously shown that ECRG4 is highly expressed in freshly isolated polymorphonuclear leukocytes (PMNs) and peripheral blood mononucleated cells (PBMCs) (where methylation of the gene promoter is very low) and in CD4- and CD8-positive T cells and CD19-positive B cells. 7,58

Our study is the first to analyse the distribution of ECRG4 immunostained cells in the main lymphatic tissues. ECRG4 was found to be strongly expressed in the cytoplasm of groups of cells located in lymphatic tissues. These cells were mainly located in the medullary compartment of lymph nodes, cortical compartment of thymus and red pulp of the spleen. Rare positive cells are also sometimes found at the margins of lymphatic tissues of the respiratory and digestive systems, and are polymorphonuclear leukocytes, macrophages and lymphocytes. Conversely, positive cells were not found in bone marrow. The fact that ECRG4 expression has not been identified in all immune cells in the lymphatic tissues, but only in some of them, may be explained with reference to their functional/proliferative state and cell sub-type. ECRG4 expression is known to be higher in resting cells than in activated ones. ${ }^{7}$ ECRG4 methylation and expression is high and low, respectively, in actively proliferating cell lines in culture, including the leukocyte lineage (e.g., Jurkat, THP1 and HL60)..$^{58}$ The ECRG4-positive cells in lymphatic tissues are probably resting/non-proliferating cells. The very low ECRG4 expression in bone marrow may also be explained as due to the high proliferative rate of this tissue. Further analysis involving markers of various lymphatic cells will be necessary to identify the positive cell types in these tissues better.

In human PMNs and PBMCs, ECRG4 is located on the cell surface and may be released, in entire or cleaved forms, in response to cell stimulation by lipopolysaccharide (LPS) and $N$-formyl peptides (fMLF). ${ }^{58} \mathrm{In}$ particular, recent analyses have shown that 20 $50 \%$ of human CD16+ leukocytes (neutrophil granulocytes) are positive for ECRG4 on the cell surface and about 10\% of CD14+ leukocytes (monocytes) are ECRG4+. A subset of leukocytes is CD14+/CD16+/ECRG4+, in which ECRG4 co-locates with the LPS receptor complex, made up of TLR4, MD2 and CD14, through molecular interaction with the C-terminus of $E C R G 4 .^{59}$ In addition, the C-terminal domain of ECRG4 (ECRG4 $\left.{ }^{133-148}\right)$ may be processed and shed in a thrombin-like consensus sequence ${ }^{58-60}$ or internalised by cells through binding to the TLR4 innate immunity receptor complex ${ }^{59}$. Another intriguing fact is that ECRG4-derived peptides have been reported to activate the NF-kB pathway in mouse peritoneal macrophages. ${ }^{58}$ In burn injuries and 
blunt traumas, a significant reduction in ECRG4 PMN surface expression has been reported, indicating release of protein in response to injury response. ${ }^{58,59}$ Thus, during injury and inflammatory responses, cell surface processing of ECRG4 by proteases may generate peptides (such as ECRG4 ${ }^{133-148}$ ) which in turn activate other cells.

It has recently been suggested that ECRG4 inhibition of tumour growth is exerted more by immunosurveillance than classic tumour suppression. ${ }^{10}$ ECRG4 does show peculiar characteristics with respect to other tumour suppressor genes, as it is located on the cell surface and sheds into extracellular milieu. ${ }^{10}$ Some authors have also pointed out that a direct anti-mitogenic effect of ECRG4 over-expression has not always been demonstrated when tumour cells are transfected in vitro. ${ }^{60}$ Conversely, ECRG4 transfection in intracranially injected glioma cells has been reported to increase survival and decrease tumour burden. The glioma micro-environment is typically characterised by immunosuppressive phenotypes, but ECRG4-expressing gliomas show greater prevalence of activated amoeboid microglia/macrophages and myeloid cells chemo-attracted to the brain tumour. Further in vitro analyses have shown that ECRG4expressing glioma tumour cells increase activation and phagocytosis in co-cultured primary microglia cells; this effect may also simply be produced by ECRG4-conditioned media. The intact thrombin cleavage site in ECRG4 was found to be necessary for microglia activation and chemo-attraction of myeloid cells, ECRG4 $4^{133-148}$ being the main peptide involved. ${ }^{60}$ In conclusion, membrane-bound ECRG4 may be considered as a sentinel factor processed by proteases (thrombin) to give soluble proinflammatory ECRG4 forms (ECRG $4^{133-148}$ ) which then exert anti-tumoral activity through recruitment and activation of immune cells. . $^{10,60}$ Moreover, ECRG4 expression is higher in a Fas-resistant variant of Jurkat cells. Conversely, Jurkat cells showing stable expression of ECRG4 by gene transfection (Jurkat ECRG4 cells) show higher survival rates and lower mitochondrial membrane depolarisation (MitoCapture) in response to anti-Fas antibody. Over-expression of ECRG4 also reduces caspase-8-dependent apoptosis induced by TNF-alpha. Instead, knock-down of endogenous ECRG4 mRNA with siRNA in Jurkat FasR cells causes decreased survival rates and increased sensitivity to alterations in mitochondrial membrane depolarisation after Fas stimulation. ${ }^{7}$

A role for ECRG4 has also been proposed for response mechanisms of mucosal and cutaneous structures to local injuries and infections. ECRG4 has been identified in the epider- mis, dermis and hair follicles of mouse skin. In a punch biopsy injury model, its expression is reduced in the granulation tissue of the injured site but is increased at the wound margins, suggesting a role as a late-injury response gene. ECRG4 transduction of fibroblasts in vitro produces a significant decrease in the rate of directional migration, in the absence of changes in proliferation. A significant delay in the rate of wound closure was found in vivo after viral-mediated intradermal gene delivery. ${ }^{37}$ As regards response to injury, it should also be noted that ECGR4 gene expression is up-regulated in regenerating caudal fin of zebrafish. ${ }^{61}$ ECRG4 is also expressed in both epithelium and stroma of mouse middle ear mucosa. Its expression was dramatically down-regulated in an experimental model of bacterially mediated otitis media, characterised by the development of mucosal hyperplasia and leukocytic infiltration. Conversely, induction of ECRG4 over-expression through transduction inhibited cell migration from an explant of inflamed mucosa in vitro, and in vivo induction of ECRG4 expression with adenovirus encoding ECRG4 attenuated mucosal thickness and inhibited inflammatory cell infiltration. ${ }^{62}$

More recently, ECRG4 gene expression has been reported to be decreased in mouse lungs after inflammatory lung injury or intravenous administration of lipopolysaccharide and, conversely, up-regulated after lung preconditioning with isoflurane anaesthesia. ${ }^{16}$

\section{Conclusions}

ECRG4 has been reported to inhibit cell proliferation and increase apoptosis in various cell types. It is down-regulated, frequently due to hypermethylation, in various tumours, including esophageal, prostate, breast and colon cancers, together with glioma (oncosuppressor function). It has recently been reported to be up-regulated in papillary thyroid cancer (oncogenic role). A role for ECRG4 has been reported in the immune system and in possible involvement in inhibition of tumor growth by immunosurveillance. Our study identified ECRG4 expression in many other structures not yet analysed from the pathophysiological viewpoint. The possible involvement of ECRG4 in the tumorigenesis of these structures (also with reference to immune function) must be examined in the future. In addition, due to the location of ECRG4 in neurons and endocrine cells and its capacity to be secreted, its role as a neurotransmitter/neuromodulator and endocrine factor may be hypothesised and is still to be clarified.

\section{References}

1. Su T, Liu HL, Lu SX, Zhao XJ, Zhou CX, Jin SQ. Cloning and identification of cDNA fragments related to human esophageal cancer. Zhonghua Zhong Liu Za Zhi 1998;20:254-7.

2. Mirabeau 0, Perlas E, Severini C, Audero E, Gascuel 0, Possenti R, et al. Identification of novel peptide hormones in the human proteome by hidden Markov model screening. Genome Res 2007;17: 320-7.

3. Götze S, Feldhaus V, Traska T, Wolter M, Reifenberger G, Tannapfel A, et al. ECRG4 is a candidate tumor suppressor gene frequently hypermethylated in colorectal carcinoma and glioma. BMC Cancer 2009; 9:447.

4. Kujuro Y, Suzuki N, Kondo T. Esophageal cancer-related gene 4 is a secreted inducer of cell senescence expressed by aged CNS precursor cells. Proc Natl Acad Sci U S A 2010;107:8259-64.

5. Ozawa A, Lick AN, Lindberg I. Processing of proaugurin is required to suppress proliferation of tumor cell lines. Mol Endocrinol 2011;25:776-84.

6. Gonzalez AM, Podvin S, Lin SY, Miller MC, Botfield H, Leadbeater WE, et al. Ecrg4 expression and its product augurin in the choroid plexus: impact on fetal brain development, cerebrospinal fluid homeostasis and neuroprogenitor cell response to CNS injury. Fluids Barriers CNS 2011; 8:6.

7. Matsuzaki J, Torigoe T, Hirohashi Y, Kamiguchi K, Tamura Y, Tsukahara T, et al. ECRG4 is a negative regulator of caspase-8-mediated apoptosis in human Tleukemia cells. Carcinogenesis 2012;33: 996-1003.

8. Dang X, Podvin S, Coimbra R, Eliceiri B, Baird A. Cell-specific processing and release of the hormone-like precursor and candidate tumor suppressor gene product, Ecrg4. Cell Tissue Res 2012;348:505-14.

9. Podvin S, Gonzalez AM, Miller MC, Dang X, Botfield H, Donahue JE, et al. Esophageal cancer related gene- 4 is a choroid plexusderived injury response gene: evidence for a biphasic response in early and late brain injury. PLoS One 2011;6:e24609.

10. Baird A, Lee J, Podvin S, Kurabi A, Dang X, Coimbra R, et al. Esophageal cancer-related gene 4 at the interface of injury, inflammation, infection, and malignancy. Gastroint Cancer Target Ther 2014;4:131-42.

11. Bi MX, Han WD, Lu SX. Using lab on-line to clone and identify the esophageal cancer related gene 4. Acta Biochim Biophys Sinica 2001;33:257-61. 
12. Fujimaki T, Tachibana N, Nakamura S, Murakami A, Funaki T, Kanai A. Screening of candidate genes for corneal endothelial dystrophy in the rabbit corneal endothelial cDNAs. Invest Ophthalmol Vis Sci 2002;43: E-Abstract 1719.

13. Tachibana N, Fujimaki T, Nakamura S, Funaki T, Murakami A. Gene expression profile study of corneal endothelium. Juntendo Med J 2002;48:216-25.

14. Steck E, Breit S, Breusch SJ, Axt M, Richter W. Enhanced expression of the human chitinase 3 -like 2 gene (YKL-39) but not chitinase 3 -like 1 gene (YKL-40) in osteoarthritic cartilage. Biochem Biophys Res Commun 2002;299:109-15.

15. Chen J, Liu C, Yin L, Zhang W. The tumorpromoting function of ECRG4 in papillary thyroid carcinoma and its related mechanism. Tumour Biol 2014 Oct 19 [Epub ahead of print].

16. Kao S, Shaterian A, Cauvi DM, Dang X, Chun HB, De Maio A, et al. Pulmonary preconditioning, injury, and inflammation modulate expression of the candidate tumor suppressor gene ECRG4 in lung. Exp Lung Res 2014 [Epub ahead of print]

17. Su AI, Wiltshire T, Batalov S, Lapp H, Ching KA, Block D, et al. A gene atlas of the mouse and human protein-encoding transcriptomes. Proc Natl Acad Sci U S A 2004;101:6062-7.

18. Roberton A, Gonzalez AM, Stopa E, Leadbeater W, Coimbra R, Johanson C, et al. Immunohistochemical evidence that Argillin, the product of the ECRG4 gene, encodes a novel neuroendocrine peptide. Endocrine Abstracts 2009;19:0C16000.

19. Albertin G, Carraro G, Parnigotto PP, Ziolkowska A, Malendowicz LK, Nussdorfer GG. Human skin keratinocytes and fibroblasts express adrenomedullin and its receptors, and adrenomedullin enhances their growth in vitro by stimulating proliferation and inhibiting apoptosis. Int J Mol Med 2003;11:635-9.

20. Albertin G, Rucinski M, Carraro G, Forneris M, Andreis P, Malendowicz LK, et al. Adrenomedullin and vascular endothelium growth factor genes are overexpressed in the regenerating rat adrenal cortex, and AM and VEGF reciprocally enhance their mRNA expression in cultured rat adrenocortical cells. Int $\mathrm{J}$ Mol Med 2005;16:431-5.

21. Tortorella C, Macchi C, Spinazzi R, Malendowicz LK, Trejter M, Nussdorfer GG. Ghrelin, an endogenous ligand for the growth hormone-secretagogue receptor, is expressed in the human adrenal cortex. Int J Mol Med 2003;12:213-7.

22. Rucinski M, Albertin G, Spinazzi R, Ziolkowska A, Nussdorfer GG, Malendo- wicz LK. Cerebellin in the rat adrenal gland: gene expression and effects of CER and [des-Ser1]CER on the secretion and growth of cultured adrenocortical cells. Int J Mol Med 2005;15:411-5.

23. Rucinski M, Ziolkowska A, Hochol A, Pucher A, Macchi C, Belloni AS, et al. Estradiol and resveratrol stimulating effect on osteocalcin, but not osteonectin and collagen-1alpha gene expression in primary culture of rat calvarial osteoblastlike cells. Int J Mol Med 2006;18:565-70.

24. Rucinski M, Ziolkowska A, Neri G, Trejter M, Zemleduch T, Tyczewska M, et al. Expression of neuromedins $\mathrm{S}$ and $\mathrm{U}$ and their receptors in the hypothalamus and endocrine glands of the rat. Int $\mathrm{J}$ Mol Med 2007;20:255-9.

25. Rucinski M, Zok A, Guidolin D, De Caro R, Malendowicz LK. Expression of precerebellins in cultured rat calvaria osteoblastlike cells. Int J Mol Med 2008;22:553-8.

26. Rucinski M, Ziolkowska A, Tyczewska M, Malendowicz LK. Expression of preproghrelin and related receptor genes in the rat adrenal gland and evidences that ghrelin exerts a potent stimulating effect on corticosterone secretion by cultured rat adrenocortical cells. Peptides 2009;30: 1448-55.

27. Rucinski M, Ziolkowska A, Szyszka M, Malendowicz LK. Cerebellin and des-cerebellin exert ACTH-like effects on corticosterone secretion and the intracellular signaling pathway gene expression in cultured rat adrenocortical cells - DNA microarray and qPCR studies. Int $\mathrm{J}$ Mol Med 2009;23:539-46.

28. Ziolkowska A, Rucinski M, Tortorella C, Tyczewska M, Nussdorfer GG, Malendowicz LK. Cultured rat calvarial osteoblast-like cells are provided with orexin type 1 receptors. Int $\mathrm{J}$ Mol Med 2007;20:779-82.

29. Porzionato A, Macchi V, Barzon L, Masi G, Iacobone M, Parenti $\mathrm{A}$, et al. Immunohistochemical assessment of parafibromin in mouse and human tissues. J Anat 2006;209:817-27.

30. Porzionato A, Rucinski M, Macchi V, Stecco C, Malendowicz LK, De Caro R. Spexin expression in normal rat tissues. $\mathrm{J}$ Histochem Cytochem 2010;58:825-37.

31. Yue CM, Deng DJ, Bi MX, Guo LP, Lu SH. Expression of ECRG4, a novel esophageal cancer-related gene, downregulated by CpG island hypermethylation in human esophageal squamous cell carcinoma. World J Gastroenterol 2003;9:1174-8.

32. Mori Y, Ishiguro H, Kuwabara Y, Kimura M, Mitsui A, Kurehara H, et al. Expression of ECRG4 is an independent prognostic factor for poor survival in patients with esophageal squamous cell carcinoma. Oncol Rep 2007;18:981-5.

33. Li LW, Yu XY, Yang Y, Zhang CP, Guo LP, Lu $\mathrm{SH}$. Expression of esophageal cancer related gene 4 (ECRG4), a novel tumor suppressor gene, in esophageal cancer and its inhibitory effect on the tumor growth in vitro and in vivo. Int $\mathrm{J}$ Cancer 2009;125: 1505-13.

34. Matsuzaki J, Torigoe T, Hirohashi Y, Tamura Y, Asanuma H, Nakazawa E, et al. Expression of ECRG4 is associated with lower proliferative potential of esophageal cancer cells. Pathol Int 2013;63:391-7.

35. Li LW, Li YY, Li XY, Zhang CP, Zhou Y, Lu SH. A novel tumor suppressor gene ECRG4 interacts directly with TMPRSS11A (ECRG1) to inhibit cancer cell growth in esophageal carcinoma. BMC Cancer 2011; 11:52.

36. Li LW, Yu XY, Li XY, Guo LP, Zhou Y, Lu SX. Mechanism of loss of human esophageal cancer-related gene 4 (ECRG4) gene expression in esophageal squamous cell carcinoma cell line EC9706. Zhonghua Zhong Liu Za Zhi 2011;33:570-3.

37. Shaterian A, Kao S, Chen L, DiPietro LA, Coimbra R, Eliceiri BP, et al. The candidate tumor suppressor gene Ecrg4 as a wound terminating factor in cutaneous injury. Arch Dermatol Res 2013;305:141-9.

38. Vanaja DK, Ehrich M, Van den Boom D, Cheville JC, Karnes RJ, Tindall DJ, et al. Hypermethylation of genes for diagnosis and risk stratification of prostate cancer. Cancer Invest 2009;27:549-60.

39. Camões MJ, Paulo P, Ribeiro FR, Barros Silva JD, Almeida M, Costa VL, et al. Potential downstream target genes of aberrant ETS transcription factors are differentially affected in Ewing's sarcoma and prostate carcinoma. PLoS One 2012;7:e49819.

40. Sabatier R, Finetti P, Adelaide J, Guille A, Borg JP, Chaffanet M, et al. Down-regulation of ECRG4, a candidate tumor suppressor gene, in human breast cancer. PLoS One 2011;6:e27656.

41. Lu J, Wen M, Huang Y, He X, Wang Y, Wu Q, et al. C20RF40 suppresses breast cancer cell proliferation and invasion through modulating expression of $\mathrm{M}$ phase cell cycle genes. Epigenetics 2013;8:571-83.

42. Fang WJ, Zheng Y, Wu LM, Ke QH, Shen H, Yuan Y, et al. Genome-wide analysis of aberrant DNA methylation for identification of potential biomarkers in colorectal cancer patients. Asian Pac J Cancer Prev 2012;13:1917-21.

43. Wang YB, Ba CF. Promoter methylation of esophageal cancer-related gene 4 in gastric cancer tissue and its clinical significance. Hepatogastroenterology 2012;59: 
$1696-8$.

44. Xu T, Xiao D, Zhang X. ECRG4 inhibits growth and invasiveness of squamous cell carcinoma of the head and neck in vitro and in vivo. Oncol Lett 2013;5:1921-6.

45. Jiang CP, Wu BH, Wang BQ, Fu MY, Yang M, Zhou Y, et al. Overexpression of ECRG4 enhances chemosensitivity to 5 -fluorouracil in the human gastric cancer SGC-7901 cell line. Tumour Biol 2013;34:2269-73.

46. Li W, Liu X, Zhang B, Qi D, Zhang L, Jin Y, et al. Overexpression of candidate tumor suppressor ECRG4 inhibits glioma proliferation and invasion. J Exp Clin Cancer Res 2010;29:89.

47. Woo JM, Park SJ, Kang HI, Kim BG, Shim $\mathrm{SB}$, Jee SW, et al. Characterization of changes in global gene expression in the brain of neuron-specific enolase/human Tau23 transgenic mice in response to overexpression of Tau protein. Int $\mathrm{J}$ Mol Med 2010;25:667-75.

48. Tadross JA, Patterson M, Suzuki K, Beale KE, Boughton CK, Smith KL, et al. Augurin stimulates the hypothalamo-pituitaryadrenal axis via the release of corticotrophin-releasing factor in rats. $\mathrm{Br} \mathrm{J}$ Pharmacol 2010;159:1663-71.

49. Malendowicz LK. Involvement of neuropeptides in the regulation of growth, structure and function of the adrenal cor- tex. Histol Histopathol 1993;8:173-86.

50. Vinson GP, Hinson JP, Tóth IE. The neuroendocrinology of the adrenal cortex. $\mathrm{J}$ Neuroendocrinol 1994;6:235-46.

51. Tóth IE, Hinson JP. Neuropeptides in the adrenal gland: distribution, localization of receptors, and effects on steroid hormone synthesis. Endocr Res 1995;21:39-51.

52. Ehrhart-Bornstein M, Hinson JP, Bornstein SR, Scherbaum WA, Vinson GP. Intraadrenal interactions in the regulation of adrenocortical steroidogenesis. Endocr Rev 1998;19:101-43.

53. Nussdorfer GG, Malendowicz LK. Role of VIP, PACAP, and related peptides in the regulation of the hypothalamo-pituitaryadrenal axis. Peptides 1998;19:1443-67.

54. Nussdorfer GG, Malendowicz LK. Role of tachykinins in the regulation of the hypothalamo-pituitary-adrenal axis. Peptides 1998;19:949-68.

55. Nussdorfer GG, Rossi GP, Malendowicz LK, Mazzocchi G. Autocrine-paracrine endothelin system in the physiology and pathology of steroid-secreting tissues. Pharmacol Rev 1999;51:403-38.

56. Huh YH, Ryu JH, Shin S, Lee DU, Yang S, $\mathrm{Oh} \mathrm{KS}$, et al. Esophageal cancer related gene 4 (ECRG4) is a marker of articular chondrocyte differentiation and cartilage destruction. Gene 2009;448:7-15.
57. Scheil-Bertram S, Kappler R, von Baer A, Hartwig E, Sarkar M, Serra M, et al. Molecular profiling of chordoma. Int $\mathrm{J}$ Oncol 2014;44:1041-55.

58. Baird A, Coimbra R, Dang X, Lopez N, Lee J, Krzyzaniak M, et al. Cell surface localization and release of the candidate tumor suppressor Ecrg4 from polymorphonuclear cells and monocytes activate macrophages. J Leukoc Biol 2012;91:773-81.

59. Podvin S, Dang X, Meads M, Kurabi A, Costantini T, Eliceiri BP, et al. Esophageal cancer-related gene-4 (ECRG4) interactions with the innate immunity receptor complex. Inflamm Res 2015;64:107-18.

60. Lee J, Dang X, Borboa A, Coimbra R, Baird A, Eliceiri BP. Thrombin-processed Ecrg4 recruits myeloid cells and induces antitumorigenic inflammation. Neuro Oncol 2015;17:685-96.

61. Padhi BK, Joly L, Tellis P, Smith A, Nanjappa P, Chevrette M, et al. Screen for genes differentially expressed during regeneration of the zebrafish caudal fin. Dev Dyn 2004;231:527-41.

62. Kurabi A, Pak K, Dang X, Coimbra R, Eliceiri BP, Ryan AF, et al. Ecrg4 attenuates the inflammatory proliferative response of mucosal epithelial cells to infection. PLoS One 2013;8:e61394. 